\title{
Liturgy and Episcopal Authority: The Evidence of the Noyon Sacramentary (London, British Library, Additional MS 82956, formerly Phillipps MS 3340)
}

\section{Sarah Hamilton}

\begin{abstract}
The liturgical evidence for bishops remains underexplored. What work there is tends to focus on those rites reserved to the bishop collected in pontificals and therefore ignores the potential of more mundane books in daily use. This case study of a sacramentary used by the bishop of Noyon in the late tenth and early eleventh centuries reveals, through a comparison with similar materials produced for contemporary communities within northern France, the ways in which the bishop's roles in the secular world were reflected in minor changes made to the liturgy in use in one of his churches. It thus casts fresh light on the less well-known see of Noyon, and at the same time demonstrates the importance of incorporating such mundane materials into modern studies of episcopacy in this period.
\end{abstract}

Recent work on the early and central medieval episcopate has greatly improved our understanding of how bishops, and the clerical communities in which they participated, understood, constructed and reconstructed their own roles in this period. ${ }^{1}$ It is striking, however, that almost all of this scholarship focuses either on the political and secular aspects of episcopal lordship, through the study of charters, vitae and other narrative writings, or upon the evidence of letters, sermons, church councils and church law for the development of episcopal office. What has been largely neglected from these studies are those texts produced to support the main business of episcopal communities, that of prayer. Similar criticisms have been made of research into monastic communities; as the musicologist Susan Boynton has observed, the 'privileging of property and politics' risks marginalising liturgical evidence. ${ }^{2}$

\footnotetext{
${ }^{1}$ The research for this paper was conducted with the support of funding for the 2016-19 project Humanities in the European Research Area: After Empire: Using and not using the past in the crisis of the Carolingian world, c. 900-c.1050 (HERA.15.076). I should like to thank Steven Vanderputten and especially Brigitte Meijns for her help as editor, and the reviewer for their constructive comments. Key works published in the last two decades include: The Bishop: Power and Piety at the First Millenium, ed. by Sean Gilsdorf (Münster: LIT Verlag, 2004); John Eldevik, Episcopal Power and Ecclesiastical Reform in the German Empire. Tithes, Lordship, and Community, 950-1150 (Cambridge: Cambridge University Press, 2012); Bischof Burchard von Worms 1000-1025, ed. by Wilfried Hartmann (Mainz: Verlag der Gesellschaft für mittelrheinische Kirchengeschichte, 200); Wilfried Hartmann, Kirche und Kirchenrecht um 900. Die Bedeutung der spätkarolingischen Zeit für Tradition und Innovation im kirchlichen Recht, Monumenta Germaniae Historica (henceforth MGH), Schriften, 58 (Hanover: Hahnsche Buchhandlung, 2008); Patterns of Episcopal Power: Bishops in Tenth and Eleventh-century Western Europe, ed. by Ludger Körntgen and Dominik Waßenhoven (Berlin and Boston: W. de Gruyter, 2011); Conrad Leyser, 'Episcopal Office in the Italy of Liudprand of Cremona, c. 890-c.970', English Historical Review, 125 (2010), 795-837; The Bishop Reformed. Studies of Episcopal Power and Culture in the Central Middle Ages, ed. by John S. Ott and Anna Trumbore Jones (Ashgate: Aldershot, 2007); John S. Ott, Bishops, Authority and Community in Northwestern Europe, c. 10501150 (Cambridge: Cambridge University Press, 2015); Steffen Patzold, Episcopus. Wissen über Bischöfe im Frankenreich des späten 8. bis frühen 10. Jahrhunderts, Mittelalter-Forschungen, 25 (Ostfildern: Thorbecke, 2008); Anna Trumbore Jones, Noble Lord, Good Shepherd. Episcopal Power and Piety in Aquitaine, 877-1050 (Leiden: Brill, 2009).

${ }^{2}$ Susan Boynton, Shaping a Monastic Identity: Liturgy and History at the Imperial Abbey of Farfa, 1000-1125 (Ithaca, NY: Cornell University Press, 2006), pp. 2-3: 'Privileging property and politics studies of the abbey's history often omit the liturgy altogether; yet inscribed in the daily performance of the liturgy lies a perspective on monastic identity that is inaccessible to purely historical, political, and archaeological narratives.'
} 
At the same time although there are several important recent studies of liturgical manuscripts made for bishops in the long tenth century by musicologists and art historians, they are largely preoccupied with questions about manuscript, liturgical and musical cultures and developments in those fields rather than about how they were used to express and support claims to episcopal lordship. ${ }^{3}$

This is not to say that mainstream historians have totally neglected liturgical books, but there is a tendency to sideline them, or to select very specific rites, most notably the coronation ordines and laudes regiae. ${ }^{4}$ But liturgical records preserve rites for all sorts of reasons. Pontificals made for the thirteenth- and fourteenth-century northern French bishops of Meaux, Cambrai, and Sens as well as Reims, included in the coronation rite the text of an anointing prayer which refers to the 'sceptres of the Saxons, Mercians and Northumbrians'.5 The presence of these rites reflects, on the one hand, textual inertia - they were copied because they should be there - and on the other, contemporary claims about the nature of episcopal authority by bishops who wished to be associated with the Crown. The nature of such claims is demonstrated by Julia Exarchos in her recent investigation of an eleventh-

\footnotetext{
${ }^{3}$ Margot E. Fassler's masterly interdisciplinary study of worship in Chartres Cathedral touches on the role of individual bishops: Margot E. Fassler, The Virgin of Chartres. Making History through Liturgy and the Arts (New Haven and London: Yale University Press, 2010); Mayr-Harting investigates certain liturgical manuscripts for the evidence they provide about particular bishops as part of a wider study of manuscripts as evidence for the culture of the Ottonian court and important ecclesiastical centres associated with it: Henry Mayr-Harting, Ottonian Book Illumination: An Historical Study, $2^{\text {nd }}$ edition (London: Harvey Miller, 1999); Rasmussen studied how and why pontificals emerged as a genre in the long tenth century: Niels Krogh Rasmussen, Les pontificaux du haut moyen âge: genèse du livre de l'évêque, ed. by Marcel Haverals, Spicilegium sacrum Lovaniense, 49 (Leuven: Spicilegium sacrum Lovaniense, 1998), pp. 452-502; Parkes makes a case study of how liturgical books can be used to study the religious history of the Ottonian Church: Henry Parkes, The Making of Liturgy in the Ottonian Church. Books, Music and Ritual in Mainz, 950-1050 (Cambridge: Cambridge University Press, 2015). See also Éric Palazzo, L'évêque et son image: l'illustration du pontifical au Moyen Age (Turnhout : Brepols, 1999). Palazzo's study of the Romano-German pontifical in its Ottonian political context is marred by Henry Parkes's recent revision of Michel Andrieu's dating and construction of the Romano-German pontifical tradition: Éric Palazzo, 'La liturgie épiscopale au Moyen Ầe et sa signification théologique et politique', in La imagen del obispo hispano en la Edad Media: Actes de la table ronde de Pampelune (7-8 mai 2000), ed. by Martin Aurell and Ángeles García de la Borbolla (Pamplona : Ediciones Universidad de Navarra, 2004), pp. 61-72; Éric Palazzo, 'La liturgie de l'occident médiéval autour de l'an mil: État de la question', Cahiers de civilisation médiévale, 43 (2000), 371-94; Henry Parkes, 'Questioning the Authority of Vogel and Elze's 'Pontifical romano-germanique", in Understanding Medieval Liturgy: Essays in Interpretation, ed. by Helen Gittos and Sarah Hamilton (Ashgate : Farnham, 2016), pp. 75-102.

${ }^{4}$ Kantorowicz's observation that medieval historians have yet to recognise the full significance of liturgical sources remains current: Ernst H. Kantorowicsz, Laudes Regiae. A Study in Liturgical Acclamations and Mediaeval ruler Worship (Berkeley and Los Angeles: University of California Press, 1958), pp. vii-ix. On coronation ordines see for example Janet L. Nelson, 'Ritual and Reality in the Early Medieval Ordines', in Politics and Ritual in Early Medieval Europe (London: Hambledon Press, 1986), pp. 329-41 (originally published in Studies in Church History, 11 (1975) 41-51); Guy Lanoë, 'Les ordines de couronnement (9301050): retour au manuscrit', in Le Roi de France et son royaume autour de l'an mil, ed. by Michel Parisse and Xavier Barral I Altet (Paris: Picard, 1992), pp. 62-72.

${ }^{5}$ Ordo XXII.A, no. 25 ('The Last Capetian Ordo'), Ordines Coronationis Franciae. Text and Ordines for the Coronation of Frankish and French Kings and Queens in the Middle Ages, ed. by Richard A. Jackson, 2 vols (Philadelphia: University of Philadelphia Press, 1995, 2000), II, p. 394. This reference occurs in other French coronation ordines, including one example from the eleventh century: Ordines XVI.18, XXI.37, XXIII.39, XXIV.40, XXV.100 (I, p. 207, II, pp. 356, 487, 540, 596). On the presence of this Anglo-Saxon reference in the Charles V coronation book, see Nelson, 'Ritual and Reality', p. 333.
} 
century pontifical compiled in Arras for the bishop of Arras-Cambrai. ${ }^{6}$ Now Köln, Erzbischöfliche Diözesan- und Dombibliothek, MS 141, this codex includes an ordo for the consecration of an emperor, a rite reserved to the pope in Rome. ${ }^{7}$ Its inclusion in a codex made in and for a diocese which lay on the border between the western kingdom of France and the eastern Reich highlights how its eleventh-century bishops were anxious to demonstrate their allegiance to the eastern Empire. ${ }^{8}$ Similarly Shane Bobrycki's 2009 study goes beyond textual analyses of the inauguration rites for the king and queen to situate them within their codicological context in a particular manuscript, a pontifical made for the archbishop of Sens; he demonstrates how their presence testifies to that archbishop's claims to possess the authority to bestow kingship in the post-Carolingian world of the late ninth century. ${ }^{9}$ As Bobyricki's and Exarchos's research into individual pontificals reveals, such collections of rites were not always intended for use as service books. They might be instead serve as library copies for study and reflection as much as practical records to support the ministry, or somewhere in between on a spectrum of works articulating claims to spiritual authority. ${ }^{10}$ In a world in which, in Henry Parkes' words, memories were 'strong and adaptive' the relationship between the liturgical written record and ministry was a complex one. ${ }^{11}$ The history of medieval rites is therefore a complicated and specialised field, but it is one we neglect at our peril. Liturgical books need to be fitted into our understanding of bishops in this period. At the same time it is clear that, whatever the challenges, there is much to be gained from looking at codices as a whole, rather than investigating individual rites in isolation from each other. ${ }^{12}$

\footnotetext{
${ }^{6}$ Julia Exarchos, 'Liturgical handbooks as Tools for Promoting Bishops' Ideological and Political Agendas: the Example of Cambrai-Arras in the Eleventh Century', Revue du Nord, 97 (2015), 317-35.

${ }^{7}$ Fols $166^{\mathrm{r}}-168^{\mathrm{v}}$; digital images of the full manuscript are available at http://www.ceec.uni-koeln.de (last accessed 17 November 2017). On its attribution to the scriptorium of Saint-Vaast, Arras see Sigrid Schultern, 'Die Buchmalerei des 11. Jahrhunderts im Kloster St. Vaast in Arras', Münchner Jahrbuch der bildenden Kunst, 7 (1956), 49-90, and now Susanne Wittekind, 'Das Pontifikale von Arras (Dom-Hs. 141): Überlegungen zur Gestaltung eines neuen bischöflichen Buchtyps', in Mittelalterliche Handschriften der Kölner Dombibliothek. Fünftes Symposium der Diözesan- und Dombibliothek Köln zu den Dom-Manuskripten (30. November bis 1. Dezember 2012), ed. by Heinz Finger and Harald Horst (Cologne: Dombibliothek mit Bibliothek St Albertus Magnus, 2014), pp. 249-82.

${ }^{8}$ Exarchos, 'Liturgical handbooks'.

${ }^{9}$ Shane Bobrycki, 'The Royal Consecration Ordines of the Pontifical of Sens from a New Perspective', Bulletin du centre d'Études médiévales d'Auxerre, 13 (2009), 131-42, on St Petersburg, National Library of Russia, MS Lat. Q. v. I.35.

${ }^{10}$ In addition to the works cited in n. 11, see Sarah Hamilton, 'The Early Pontificals: The Anglo-Saxon Evidence Reconsidered from a Continental Perspective', in England and the Continent in the Tenth Century. Studies in Honour of Wilhelm Levison (1876-1947), ed. by David Rollason, Conrad Leyser, and Hannah Williams, Studies in the Early Middle Ages, 37 (Turnhout: Brepols, 2010), pp. 411-428.

${ }^{11}$ Parkes, The Making of Liturgy, pp. 2 (quote), 12 and passim; Helen Gittos, 'Researching the History of Rites', in Understanding Medieval Liturgy, pp. 13-37 (pp. 20-23); Sarah Hamilton, 'Interpreting Diversity: Excommunication Rites in the Tenth and Eleventh Centuries', in Understanding Medieval Liturgy, 125-58.

${ }^{12}$ In addition to the works by Exarchos, 'Liturgical handbooks', and Bobyrcki, 'Royal Consecration Ordines', for outlines of the challenges and how they may be overcome see those by Parkes, The Making of Liturgy, and Gittos, 'Researching the History of Rites', pp. 23-36. These scholars are mindful of the warning given by Christopher A. Jones, 'The Chrism Mass in Late Anglo-Saxon England', in The Liturgy of the Late Anglo-Saxon Church, ed. by Helen Gittos and M. Bradford Bedingfield, Henry Bradshaw Subsidia 5 (London: Henry Bradshaw Society, 2005), pp. 105-42 (p. 128): 'A fast rule in the study of liturgical manuscripts generally, and of pontificals especially, is that relations between books as wholes cannot be argued merely on the evidence of
} 
As the above review suggests, recent scholarship on pontificals has focussed a good deal on manuscripts from northern France and Lotharingia. ${ }^{13}$ Its focus has been firstly on the evidence of pontificals, that is collections of materials to support occasional rites reserved to the bishop, and secondly on records of the Office as evidence for both saints' cults and early medieval chant. ${ }^{14}$ Pontificals remain the preserve largely of historians, whilst gradualantiphonaries have attracted the attention of musicologists. But as recent research has demonstrated, both pontificals and gradual-antiphonaries are both more likely to be exceptional texts, reflecting the interests of their compilers and the traditions of their users rather than being composed for use in services. ${ }^{15}$ Given these challenges, this article approaches the subject of episcopal liturgy from a different perspective, that of a sacramentary-benedictional made for a community associated with one of the less well studied bishoprics of the province of Reims in the tenth and eleventh centuries. Containing the prayers to be said by the priest celebrating Mass, sacramentaries are to be found across the early medieval west from local to cathedral churches, and in both monastic and secular communities. ${ }^{16}$ Although they also included specific blessings, collections of such texts, known to modern scholars as benedictionals, began to be assembled, first in libelli as supplements to sacramentaries and pontificals from the late ninth century, and then, from the tenth century onwards, as books in their own right. ${ }^{17}$ By investigating the evidence in this manuscript, when compared to others written in the province of Reims belonging to the same genre, this essay aims to demonstrate the value of more mundane books for what they can tell us about contemporary understandings of episcopal office. The codex which is the subject of

this or that single component. And yet the working out of such larger relationships has few options but to proceed ritual by ritual.'

${ }^{13}$ See also the extensive investigation of the sacramentary-pontifical composed for Ratoldus, abbot of Corbie (972-86) in the late tenth century in the edition by Nicholas Orchard: The Sacramentary of Ratoldus (Paris, Bibliothèque nationale de France, lat. 12052), ed. by Nicholas Orchard, Henry Bradshaw Society 116 (London: Henry Bradshaw Society, 2005), pp. xiii-cxciii.

${ }^{14}$ On pontificals as a genre see Rasmussen, Les pontificaux, pp. 452-502. For north French pontificals in this period see especially Orchard's introduction to The Sacramentary of Ratoldus, pp. xiii-cxciii; for the twelfth and thirteenth centuries see Mary C. Mansfield, The Humiliation of Sinners. Public Penance in Thirteenth-century France (Ithaca and London: Cornell UP, 1995). On the evidence for the Office, see Jean-François Goudesenne, Les Offices historiques ou historiae composés pour les fêtes des saints dans la Province ecclésiastique de Reims, 775-1030 (Turnhout: Brepols, 2002). Also on mostly later material see Sacramentaire et martyrologe de l'abbaye de Saint-Remy: Martyrologe, calendrier, ordinaires et prosaire de la metropole de Reims (VIII ${ }^{e}-X I^{e}{ }^{e}$ siècles), publiés d'après les manuscrits de Paris, Londres, Reims et Assise, ed. by Ullysse Chevalier, Bibliothèque liturgique, 7 (Paris : Alphonse Picard, 1900).

15 For the gradual-antiphonary of Mont-Renaud, possibly from Noyon, possibly from Saint-Denis, see Antiphonaire du Mont-Renaud: antiphonaire de la messe et de l'office, $X^{e}$ siecle, Paléographie musicale 16 (Solesmes: l'Abbaye de Saint-Pierre, Solesmes, 1955); on its attribution to Saint-Denis see G.M. Beyssac, 'Le Graduel-Antiphonaire de Mont-Renaud', Revue de musicologie, 40 (1957), 131-150. On the extent to which both pontificals and gradual-antiphonaries are a product of scribal decisions see Parkes, The Making of Liturgy, pp. 8-10.

${ }^{16}$ Cyrille Vogel, Medieval Liturgy: An Introduction to the Sources, revised and translated by William G. Storey and Niels Krogh Rasmussen with the assistance of John K. Brooks-Leonard (Washington DC: The Pastoral Press, 1986), pp. 61-134; Marcel Metzger, Les sacramentaires, Typologie des sources du moyen âge occidental, 70 (Turnhout: Brepols, 1994); Parkes, The Making of Liturgy, pp. 7-10.

17 'The history of this book as distinct from the pontifical has not yet been the object of the thorough study it deserves': Éric Palazzo, A History of Liturgical Books from the Beginning to the Thirteenth Century, trans. by Madeleine Beaumont (Collegeville, Minnesota: The Liturgical Press, 1998), p. 200. On texts themselves see Corpus Benedictionum Pontificalium ed. by Edmond Moeller, 4 vols, CCSL, 162 (Turnhout: Brepols, 1971-79). 
this case study is a late tenth-century sacramentary benedictional from Noyon, now British Library, Additional MS 82956.

Noyon, in the province of Reims, is one of the less well-known sees in the early medieval province of Reims. It was not home to an influential school, unlike the neighbouring see of Laon, nor did it produce writers on a par with Flodoard, Gerbert and Richer in the tenth-century see of Reims, or the anonymous authors of the Gesta episcoporum Cameracensium and Acta Synodi Atrebatensis in eleventh-century Cambrai to the north. ${ }^{18}$ But it is one of the sees which acquired powers of temporal episcopal lordship from the king in the course of the tenth and eleventh centuries. ${ }^{19}$ At the same time we are fortunate to have a range of liturgical books surviving from Noyon from the ninth, tenth, eleventh and thirteenth centuries. ${ }^{20}$ Therefore Noyon makes a good place to begin to look at the evidence of sacramentaries for what they can tell us about bishops in this period.

\footnotetext{
${ }^{18}$ On Laon see John J. Contreni, The Cathedral School of Laon from 850 to 930: Its Manuscripts and Masters, Münchener Beiträge zur Mediävistik und Renaissance-Forschung, 29 (Munich: Arbeo-Gesellschaft, 1978) and John J. Contreni, 'The Laon Formulary and the Cathedral School of Laon at the Beginning of the Tenth Century' in John J. Contreni, Learning and Culture in Carolingian Europe: Letters, Numbers, Exegesis, and Manuscripts, Variorum Collected Studies Series, 974 (Farnham: Ashgate, 2011), no. X. On Flodoard see Flodoard of Reims, Historia Remensis ecclesiae, ed. by Martina Stratmann, MGH, Scriptores (henceforth SS), 36 (Hanover: Hahnsche Buchhandlung, 1998); Les Annales de Flodoard publiées d'après les manuscrits avec une introduction et des notes, ed. by Philippe Lauer, Collection de textes pour servir à l'enseignement de l'histoire, 39 (Paris: Alphonse Picard, 1905); The Annals of Flodoard of Reims 916-66, trans. by Steven Fanning and Bernard S. Bachrach (Peterborough, Ont.: Broadview Press, 2004); Michel Sot, Un historien et son Église. Flodoard de Reims (Paris: Librairie Arthème Fayard, 1993); Edward Roberts, 'Flodoard, the Will of St Remigius and the See of Reims in the Tenth Century,' Early Medieval Europe, 22 (2014), 201-30; Edward Roberts, 'Hegemony, Rebellion and History: Flodoard's Historia Remensis Ecclesiae in Ottonian Perspective', Journal of Medieval History, 42 (2016), 155-76. On Richer see Richer of Saint-Rémi, Histories, ed. and trans. by Justin Lake, 2 vols, Dumbarton Oaks Medieval Library, 10 and 11 (Cambridge, Mass: Harvard UP, 2011); Jason Glenn, Politics and History in the Tenth Century: The Work and World of Richer of Rheims (Cambridge: Cambridge UP, 2004); Justin Lake, Richer of Saint-Rémi: The Methods and Mentality of a Tenth-century Historian (Washington DC: Catholic University of America Press, 2013). On Cambrai: Gesta episcoporum Cameracensium, ed. Ludwig C. Bethmann, MGH SS, 7 (Hanover: Hahnsche Buchhandlung, 1846), pp. 393-89; Acta Synodi Atrebatensis, Vita Autberti, Vita Gaugerici: varia scripta ex officina Gerardi exstantia, ed. by Steven Vanderputten and Diane J. Reilly, Corpus Christianorum Continuatio Mediaevalis, 270 (Turnhout: Brepols, 2014); Theo M. Riches, 'Episcopal Historiography as Archive. Some Reflections on the Autograph Manuscript of the Gesta episcoporum Cameracensium (MS Den Haag KB 75 F 15)', Jaarboek voor Middeleeuwse Geschiedenis, 10 (2007), 7-46; Steven Vanderputten and Diane J. Reilly, 'Reconciliation and Record Keeping: Heresy, Secular Dissent and the Exercise of Episcopal Authority in Eleventh-century Cambrai', Journal of Medieval History, 37 (2011), pp. 343-57. Contrast the extensive historical narratives compiled in Reims and Cambrai with the brief text compiled by the treasurer of Noyon, Guy, 1064x1068/9; for an assessment and edition of this text see Olivier Guyotjeannin, 'Noyonnais et Vermandois au $\mathrm{X}^{\mathrm{e}}$ et $\mathrm{XI}^{\mathrm{e}}$ siècles. La déclaration du trésorier Guy et les premières confirmations royales et pontificales des biens du chapitre cathédrale de Noyon', Bibliothèque de l'École des chartes, 139 (1981), 143-89.

${ }^{19}$ Olivier Guyotjeannin's study demonstrates how episcopal lordship there evolved over the course of the tenth to twelfth centuries: Episcopus et comes: affirmation et déclin de la seigneurie épiscopale au nord du royaume de France (Beauvais-Noyon, Xe - début XIII ${ }^{e}$ siècle) (Genève: Droz, 1987). See also his 'La seigneurie episcopale dans le royaume de France ( $\mathrm{X}^{\mathrm{e}}-\mathrm{XIII}^{\mathrm{e}}$ siècles)', in Chiesa e mondo feudale nei secoli X-XII. Atti della dodicesima Settimana internazionale di studio Mendola, 24-28 agosto 1992. Miscellanea del Centro di studi medioevali, 59 (Milan, 1995), pp. 151-88, and Reinhold Kaiser, Bischofsherrschaft zwischen Königtum und Fürstenmacht. Studien zur bischöflichen Stadtherrschaft im westfränkisch-französischen Reich im frühen und hohen Mittelalter (Bonn: Röhrscheid, 1981), pp. 565-72.

${ }^{20}$ Reims, Bibliothèque municipale (henceforth BM), MS 213 (sacramentary, s.ix ${ }^{3 / 4}$, seemingly composed for Ragenelmus, bishop of Noyon-Tournai (860-79) and subsequently given to Reims), St Petersburg, Nat. lib., MS Q.v.I.41 (sacramentary, s.ix ${ }^{3 / 4}$ ); on these see Le Sacramentaire grégorien. Ses principales formes d'après les
} 
The sacramentary is the main book needed by a priest to celebrate the mass. ${ }^{21}$ It includes the canon of the mass, and then, arranged by days of the year, the specific mass prayers for feasts in the temporale and sanctorale, as well as those for various votive masses. ${ }^{22}$ This particular codex also includes a series of blessings, and rites for the consecration of a church, for baptism on Holy Saturday, for the administration of penance, and rites for the dying. ${ }^{23}$ It is a version of the Supplemented Hadrianum Gregorian Sacramentary promoted by Benedict of Aniane which circulated widely in ninth- and tenthcentury Francia. ${ }^{24}$ As the modern editor of the Hadrianum has observed, it was normal for individual churches to elaborate on the text of the Gregorian Sacramentary and adapt it for local use: 'The same thing happened practically everywhere: every individual in charge of a church gave free rein to his pastoral concern and tried to have a sacramentary with a handy arrangement of all the texts he might possibly need. ${ }^{25}$

Sacramentaries belonged to both monastic and secular communities. Despite the absence of any evidence for its provenance before it came to England in 1819, the internal evidence of the text itself suggests that this manuscript was made for the community of SaintEligius in Noyon for use by the bishop of the city. Saint-Eligius was a house just outside the walls of the city and was under the authority of the bishop. ${ }^{26}$ For much of the tenth century it was a house of canons, but was seemingly restored to monastic use by Bishop Liudolf (97986) sometime during his pontificate. ${ }^{27}$ Through the patronage of the bishop it was thus linked to the cathedral of Notre Dame and Saint-Médard in Noyon.

plus anciens manuscrits, $3^{\text {rd }}$ edn, ed. by. Jean Deshusses, 3 vols, Spicilegium Friburgense, 16, 24, 28 (Fribourg: Éditions universitaires Fribourg, 1988, 1992), I, 41, 46. London, British Library (henceforth BL), Egerton Ms 857 (s.x-xii, gradual) on which see Emma Hornby, Medieval Liturgical Chant and Patristic Exegesis: Words and Music in the Second-mode Tracts (Woodbridge: Boydell, 2009), pp. 52, n. 49, 156, n. 17, 218. Laon, BM, MS 244 (pontifical, s. xiii ${ }^{\text {in }}$ ), on which see Victor Leroquais, Les Pontificaux manuscrits des bibliothèques publiques de France, 4 vols (Paris: Bibliothèque de l'abbaye Saint-Martin Ligugé, 1937), I, pp. 164-69; Abbeville, BM, MS 7 (missal, s. xiii), on which see Leroquais, Les Pontificaux, II, pp. 109-10: Paris, Bibliothèque nationale de France (henceforth BnF), MS lat. 17334 (pontifical, s.xiii ${ }^{2}$ ), Leroquais, Les Pontificaux, II, pp. 211-14. Edmond Martène recorded various manuscripts at Noyon in the eighteenth century, including a pontifical attributed to Bishop Ratbod of Noyon (989-987), but these have since been lost: AiméGeorges, Martimort, La documentation liturgique de Dom Edmond Martène. Étude codicologique, Studi e Testi, 279 (Vatican City: Biblioteca Apostolica Vaticana, 1978), pp. 159-162; Aimé-Georges Martimort, 'Un Gélasien du VIIIe siècle: le sacramentaire de Noyon', in Miscellanea Amato Pietro Frutaz (Rome: Tipografia Guerra, 1978), pp. 183-206.

${ }^{21}$ Metzger, Les sacramentaires, pp. 33-37; Palazzo, A History of Liturgical Books pp. 21-61.

${ }^{22}$ Metzger, Les sacramentaires, pp. 35-36; Jean Deshusses, 'Les sacramentaires. État actuel de la recherche', Archiv für Liturgiewissenschaft, 24 (1982), 19-46, published in English as 'The Sacramentaries: A Progress Report', trans. by Father Chrysogonus, Liturgy, 18 (1984), 17-60.

${ }^{23}$ For a description of the contents see D.H. Turner, 'A $10^{\text {th }}-11^{\text {th }}$ Century Noyon Sacramentary', in Studia Patristica V: Papers presented to the third international conference on patristic studies held at Christ Church, Oxford, 1959, Part III: Liturgica, Monastica et Ascetica, Philosophica, ed. by Frank Leslie Cross, Texte und Untersuchungen, 80 (Berlin: Akademie Verlag, 1962), 143-151. See now the description in the British Library catalogue available at http://bit.ly/2BekZ9G (last accessed 21 December 2017).

${ }^{24}$ Le Sacramentaire grégorien, ed. by Deshusses. The text of Additional MS 82956 has been closely compared to Paris, BnF, MS lat. 12051, on which see Klaus Gamber, Sakramentartypen. Versuch einer Gruppierung der Handschriften und Fragmente bis zur Jahrtausendwende, Texten und Arbeiten herausgegeben durch die Abtei Beuron, 49/50 (Beuron: Beuroner Kunstverlag, 1958), pp. 145-55.

${ }^{25}$ Deshusses, 'The Sacramentaries', p. 58.

${ }^{26}$ Guyotjeannin, Episcopus et comes, p. 34.

${ }^{27}$ Guyotjeannin, Episcopus et comes, pp. 42-43. 
The main body of the text includes blessings for St Médard and St Eligius, both important early bishops in the history of the see. ${ }^{28}$ Médard was the bishop who established the seat of the see at Noyon in the sixth century, although his body was subsequently moved to Soissons. Eligius was the seventh-century bishop of Noyon. ${ }^{29}$ That this sacramentary was intended for use by the community of Saint-Eligius is underlined by two further references to his cult. The dedication of the altar to St Eligius is mentioned in blessing for candles before the prayers for catechumens on Holy Saturday: 'ut nos tui ministros altaris omneque beati eligii confessoris tui clericum cum populo praesenti in pulchritudinem pacis [...] ${ }^{3}{ }^{30}$ Secondly, the Mass 'for the martyr or confessor to whom the church is dedicated' specifically names Eligius as the confessor being addressed and highlights his name in capitals. ${ }^{31}$ This is a version of a mass commonly found in the Supplemented Hadrianum tradition. ${ }^{32}$ In other manuscripts the dedicatee's name is usually left blank; thus the mention of the patron here reaffirms the book's connection to the community of Saint-Eligius.

That the book was used by a community associated with the bishop seems likely from the fact that someone has taken the trouble to amend a version of the conventional Hadrianic text for a votive mass for a dead bishop to insert above the line plural endings for the references to the dead bishop so that it becomes a mass in memory of dead bishops. ${ }^{33}$ That attention was paid to the copying of this particular Mass set is also clear from the inclusion of a rubric referring to the reading to be said after the offertory prayer. That this manuscript was intended for the bishop of Noyon is revealed by the various texts added in slightly later, less formal hands, on the first nine folios at the front of the manuscript. These include an excommunication formula to be delivered by the bishop of Noyon. ${ }^{34}$ Alongside this reference to a rite reserved to the bishop are other texts for episcopal rites, including one for

\footnotetext{
${ }^{28}$ BL, MS Addit. 82956, fols 100v-101 : BENEDICTIO IN NATALIS SANCTI MEDARDI. Deus fundator fidei indultor [...]; ibid., fols 134 ${ }^{\mathrm{r}} \mathrm{v}$ : BENEDICTIO IN NATALIS SANCTI ELIGII. Deus qui beatissimum eligium praesulem tuum [...]. Both benedictions are based on texts from the eighth-century or Frankish Gelasian tradition: Liber sacramentorum Gellonensis, ed. by Antoine Dumas and Jean Deshusses, Corpus Christianorum Series Latina (henceforth CCSL), 159-159A (Turnhout, Brepols, 1981) (where they are used for St Hilarius and St Martin respectively), p. 288 (nr. 2067) and 292 (nr. 2079). Both sets were widely used to support local cults: Corpus Benedictionum Pontificalium ed. by Moeller, nos. 910 and 807, I, pp. 367, 323. The flexibility of these texts is demonstrated by their adaptation for other cults in another West Frankish manuscript written in the province of Reims in the late tenth century: The Sacramentary of Ratoldus, ed. by Orchard, nos 433 (St Vaast) and 442 (St Valentine), pp. 122, 124.

${ }^{29}$ On the vitae as evidence for the cults of St Medard and St Eligius see Léon van der Essen, 'Vies de saint Médard et de saint Éloi', Annuaire de l'Université catholique de Louvain, 68 (1904), 372-90; Charles Mériaux, Gallia irradiata. Saints et sanctuaires dans le nord de la Gaule du haut Moyen Âge, Beiträge zur Hagiographie, 4 (Stuttgart: Franz Steiner Verlag, 2006), pp. 193-94.

${ }^{30}$ BL, MS Addit. 82956, fols $74^{\mathrm{r}}-74^{\mathrm{v}}$.

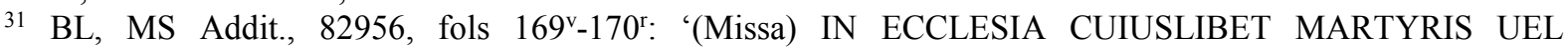
CONFESSORIS. Propitiare quaesumus domine nobis famulis tuis per sancti confessoris tui ELIGII qui in praesenti requiescit ecclesia merita gloriosa, ut eius pia intercessione ab omnibus protegamur aduersis. Per dominum'. Eligius's name is also highlighted in the other prayers in this mass set.

${ }^{32}$ Le Sacramentaire Grégorien, ed. by Deshusses, II, pp. 51-52 (nos 1877-78, 1880).

33 MISSA PRO EPISCOPO DEFUNCTO, BL, MS Addit. 82956, fols $196^{\mathrm{r}}-197^{\mathrm{v}}$. Cf. Le Sacramentaire Grégorien, ed. by Deshusses, I, pp. 346-47 (nos 1010, 1011, 1012, 1014), II, pp. 198, 201-02.

${ }^{34}$ BL MS Addit., 82956, fol. 1'v . The formula begins 'Dictis sanctorum patrum monemus et exemplis pervasores sanctae dei aecclesiae a consortio sanctorum et a communione christianitatis priuari. Accirco ego humilis noviomensis ecclesiae pastor cum omni grege nobis commisso'.
} 
confirmation. ${ }^{35}$ Additional texts were also later interpolated into the main body of the text on extra leaves including two prayers for the episcopal rite of abbatial consecration. ${ }^{36}$ The evidence of these later additions - both on additional leaves at the beginning and in the main text - suggests that this is a codex adapted shortly after it was made with the sorts of texts that a bishop would need. Whilst not every addition pertains to rites reserved to the bishop an initial supplementary quire written in a more informal hand includes two ordines missae, for example -- the inclusion of the preface to a missa in ordinatione presbiteri help confirm the picture outlined above of supplements being made to the original sacramentary with the bishop's office in mind. ${ }^{37}$ It was revised by someone interested in rites for the excommunication, confirmation of children, consecration of an abbot, tonsuring of the clergy and ordination of priests.

London, British Library, Additional MS 82956 is a tall, narrow book, measuring some $390 \mathrm{~mm}$ by $150 \mathrm{~mm}$. This shape is generally associated with the liturgical books known as cantatoria. ${ }^{38}$ A cantatorium is a record of the responsorial chants sung between the Epistle and the Gospel at Mass, and is generally assumed by musicologists to have been compiled for the cantor responsible for leading the singing. ${ }^{39}$ The typical long-thin shape of cantatoria may, however, owe less to their function, than to the fact that they were designed to fit existing covers. ${ }^{40}$ Ruth Steiner and David Hiley proffered this explanation because the similarity in form of various manuscripts is not always matched by similarity in content. ${ }^{41}$ It is possible that a similar desire to reuse existing covers lay behind the design of the shape of the Noyon sacramentary. It is certainly striking that all the other surviving sacramentaries and pontificals copied in this region in the tenth and eleventh centuries are much squarer. ${ }^{42}$ Indeed, I am currently only aware of one sacramentary manuscript which adopts a similar shape to this one: this is Cambrai, Mediathèque, MSS 162-63, a late ninth-century augmented

\footnotetext{
${ }^{35}$ BL MS Addit., 82956, fols. 3 ${ }^{\text {r-v }}$.

${ }^{36}$ Prayers headed Ad abbatem faciendum: BL MS Addit., 82956, fol. 12 ${ }^{\mathrm{r}}{ }^{ } \mathrm{v}$.

37 Ordines missae, BL, Addit. MS 82956, fols $2^{\mathrm{r}}-3^{\mathrm{v}}, 4^{\mathrm{r}}-5^{\mathrm{r}}$; text of a prayer from the Hadrianum Missa in ordinatione presbiteri, V.D. qui dissumulatis peccatis, added on fol. $5^{\mathrm{r}}$.

${ }^{38}$ E.g. St Gallen, Stiftsbibliothek, MS 359 measures $280 \times 125 \mathrm{~mm}$.

${ }^{39}$ Peter Jeffery, 'An Early Cantatorium Fragment Related to MS Laon 239', Scriptorium, 36 (1982), $245-52$ (p. 246).

${ }^{40}$ Ruth Steiner and David Hiley, 'Cantatorium' in The New Grove Dictionary of Music and Musicians, edited by Stanley Sadie, 2nd edition, 29 vols (London: Macmillan, 2001), V, p. 42.

${ }^{41}$ Steiner and Hiley, 'Cantatorium', p. 42. They also caution against regarding cantatoria as practical books on the grounds that they contained only the chants required by one singer because 'the manner in which the material is arranged does not suggest that the book was used in performance'.

${ }^{42}$ E.g. Paris, BnF, MSS lat. 1238 (sacramentary, Reims, s. x, 300 x 220 mm), lat. 9432 (sacramentary, s. $x^{\text {in }}, 320$ x $235 \mathrm{~mm}$ ), lat 12051 (sacramentary-pontifical written at Corbie, s. ix ${ }^{\mathrm{ex}}$, probably for bishop of Beauvais, $310 \mathrm{x}$ $240 \mathrm{~mm}$ ), lat. 12052 (the Sacramentary of Ratoldus, Corbie, s. x ${ }^{4 / 4}, 320$ x $260 \mathrm{~mm}$ ); Reims, BM, MSS 213 (sacramentary, Saint Thierry, Reims, s. ix, 344 x 262 mm), 214 (sacramentary, Saint Thierry, Reims, s. x², 300 x $00 \mathrm{~mm}$ ), 340 (pontifical, Reims, s.x ex, 258 x $202 \mathrm{~mm}$ ) and 341 (pontifical, Reims, s.xi², 260 x $201 \mathrm{~mm}$ ); Oxford, Bodleian Library, MS Bodley 579 (the 'Leofric' Missal, a sacramentary-cum-pontifical copied at Arras c. 900 and subsequently extensively supplemented in later tenth and eleventh century southern England, s.x/xi, 195 x 145 mm); St Petersburg, Nat. lib., Ms Q.v.I.35 (pontifical, Sens, s. ix ${ }^{\text {ex }}$, on which see A. Staerk, Les manuscrits latins conservés du $V^{e}$ au XIII siècle à la bibliothèque impériale de Saint-Pétersbourg: description, textes inédits, reproductions autotypiques, 2 vols (St Petersburg, 1910), I, pp. 151-73 and pl. XXII; Guy Lobrichon, 'Nouvelles recherches sur le rituel pontifical de Sens au IX siècle,' Bulletin de la Société nationale des antiquaires de France (1992), 191-200; St Petersburg, Nat. lib., Ms Q.v.I.41(sacramentary, Noyon, s. ix, on which see Staerk, Les manuscrits latins, I, pp. 74-127).
} 
Hadrianum sacramentary, probably from Saint-Vaast in Arras, which measures $35 \mathrm{~mm} \times 12.5$ $\mathrm{mm} .{ }^{43}$ Saint-Vaast was one of the houses which in the late ninth century copied at least two versions of the Hadrianum for churches in northern France. ${ }^{44}$ British Library, Additional MS 82956 is very similar in shape, layout and script -- a sort of monumental half uncial - to Cambrai MSS 162-63 but the standard of decoration is much less elaborate, being confined to ink rather than the gold leaf used in the ninth-century manuscript. It is therefore possible that Additional MS 82956 was modelled on an earlier manuscript. ${ }^{45}$ There are other hints that its model could have come from Saint Vaast: Additional MS 82956 includes a mass for the burial of Saint Vaast, and according to Flodoard of Reims, the mid-tenth-century bishop of Noyon (937-50), Transmarus, had previously been prior of Saint-Vaast. ${ }^{46}$ Seemingly based on a ninth-century model, what we cannot know is whether this manuscript is a work of deliberate conservatism, or rather a product of inertia. But the comparison with other sacramentaries and pontificals copied in the province of Reims in this period, all of which adapted a more conventional, squarer, format, suggests that that selected for Additional MS 82956 was the result of deliberate choices. Whilst is impossible to determine how far these were made for practical reasons - a desire to reuse existing book covers, perhaps - or for more ideological ones, it is clear that the clerical community of Saint Eligius modelled their sacramentary on earlier precedents. ${ }^{47}$

There are other features of this manuscript which are more innovative, not to say unique. Included amongst the various votive masses of Benedict of Aniane's Supplement to the Hadrianum is a (daily) mass for the king under the rubric missa pro rege; this mass set was routinely copied into manuscripts of the Hadrianum between the ninth and eleventh centuries, generally under the title Missa cotidiana pro rege. ${ }^{48}$ Despite its rubric, Additional MS 82956 departs from other surviving sacramentaries in the Gregorian tradition made in the

\footnotetext{
${ }^{43}$ Several images of this manuscript are available through the CNRS IRHT Bibliothèque virtuelle manuscrits médiévaux: http://bit.ly/2AAMBp5 (last accessed 15 December 2017). See also Le Sacramentaire Grégorien, ed. by Deshusses, I, p. 35.

${ }^{44}$ For similarities in the decoration of two manuscripts copied at Saint-Vaast, Arras in late ninth and early tenth centuries, see The Leofric Missal, ed. by Nicholas Orchard, 2 vols, Henry Bradshaw Society, 113-114 (London: Boydell Press, 2002), pp. 16-20; he cites Cambrai, Mediathèque, MSS 162-3 (on which see Leroquais, Les sacramentaires, I, pp. 36-38) and Oxford, Bodleian Library, MS Bodley 579 (Leofric A).

${ }^{45}$ The copies of the supplemented Hadrianum made at Saint-Amand in the second half of the ninth century have attracted rather more attention, but these are all squarer in layout: Le Mans, BM, MS 77 (digital images available online through CNRS IRHT Bibliothèque virtuelle des manuscrits mediévaux, http://bvmm.irht.cnrs.fr/ (last accessed 15 December 2017)); New York, Pierpont Morgan Library, Glazier MS 57 (digital images available online at http://www.themorgan.org/manuscript/76982 (last accessed 15 December 2017); St Petersburg, Nat. lib., MS Q.v.I.41 (Staerck, Les manuscrits latins, I, pp. 74-127 and pl. XVII); Reims, BM, MS 213 (digital images available online http://bvmm.irht.cnrs.fr/consult/consult.php?reproductionId=2176; last accessed 15 December 2017); Stockholm, Kungliga Biblioteket, MS Holm A. 136; Paris, BnF, MS lat. 2290 (digital images available online via Gallica: https://bit.ly/2HbRTeR; last accessed 15 December 2017); Vienna, Österreichische Nationalbibliothek, MS lat. 958.

${ }^{46}$ BL, Addit. MS 82956, fol. 32 $2_{-}^{\mathrm{r}} \mathrm{v}$ : 'Depositio Sancti Vedasti'. 'Waltberto quoque Noviomagensium praesule defuncto, succedit Transmarus monasterii Sancti Vedasti praepositus': Les Annales de Flodoard ed. by Lauer, a. 937, p. 65.

${ }^{47}$ For a similar practice at late tenth-century Corbie see Julia Crick's observation: 'At Saint-Bertin under Abbot Odbert scribes allegedly practised an archaizing style which calqued ninth-century script from Tours sometimes so successfully as to confuse modern commentators'. Julia Crick, 'Insular history? Forgery and the English past in the Tenth Century', in England and the Continent in the Tenth Century, pp. 515-44 (p. 529).

${ }^{48}$ Fol. 170v-171r; cf. Le Sacramentaire grégorien, ed. by Deshusses, I, p. 425 (nos 1270-1272).
} 
archdiocese of Reims in the late ninth and tenth centuries in that someone has gone through and added an interlinear gloss above the line in the prayers so it becomes a daily mass for kings, plural. ${ }^{49}$ The closest parallel is the adaptation of the title of this mass set to refer to plural kings in the late tenth-century sacramentary-pontifical copied for Ratoldus, abbot of Corbie - missa cotidiana pro regibus; in that mass set, however, the actual prayer texts are given only in the singular. ${ }^{50}$ The decision to include an interlinear gloss so that this mass set could be said for more than one king helps perhaps to date when these additions to the manuscript were made. The missa cotidiana pro rege features in the coronation ordo in the late tenth-century Ratoldus Sacramentary from Corbie; other examples of that particular coronation ordo omit it. ${ }^{51}$ Hugh Capet was crowned at Noyon on 1 June 987 and, as RobertHenri Bautier showed, only subsequently anointed at Reims; his son, Robert the Pious, was crowned as king some 6 months later in Orléans cathedral on 30 December $987 .{ }^{52}$ It is therefore possible that this amendment was made sometime between Robert's coronation and Hugh Capet's death on 24 October 996. Palaeography is not, however, an exact science; it is, of course, also possible that the reference to two kings relates to the association of one of Robert's sons with his rule, once they came of age; Hugh was formally crowned king at Pentecost 1017 at nearby Compiègne, and after Hugh's death, his brother Henry was crowned in $1027 .{ }^{53}$ The bishops of Noyon were present at all four coronations of these Capetian kings and their sons. ${ }^{54}$ It is therefore more likely - given the addition of other texts which can be associated with the monastic reform of Saint- Eligius in the 980s - that these glosses should be linked to the first two Capetian kings, Hugh and Robert the Pious. The bishops of Noyon had close connections to the new Capetian regime. As Robert-Henri Bautier suggests, Noyon was probably chosen as the site for Hugh Capet to be acclaimed king in June 987 because it had been the site of Charlemagne's initial coronation in $768 .{ }^{55}$ The amendment to allow the daily mass to be said for kings in the Noyon codex underlines what Guyotjeannin's and others' work on the royal acta has already made clear, namely that the bishops of Noyon were closely connected to the early Capetian kings, and that this close relationship explains how they came to assume local secular lordship at this time. ${ }^{56}$ The evidence for this

\footnotetext{
${ }^{49}$ Compare: Reims, BM, MS 213, f. $139^{\mathrm{r}}$ (Saint-Amand for Saint-Thierry, Reims, c. 869); Paris, BnF, MS lat. 12051, fol. 272'-v (s. ix ${ }^{\text {med }}$, Corbie for Beauvais); Reims, BM, MS 214, fol. $147^{\mathrm{r}}$ (Saint-Thierry, Reims, s. ${ }^{\mathrm{ex}}$ ); Paris, BnF, MS lat. 12052, fols 29 $9_{-}^{\text {rv }}$ (s. ${ }^{\text {ex }}$, Corbie); Oxford, Bodl. Lib., MS Bodley 579, fol. $217^{\mathrm{r}}$ (Leofric 'A', Saint-Vaast, Arras, s. $\mathrm{x}^{\mathrm{ex}}$ ).

${ }^{50}$ The Sacramentary of Ratoldus, ed. by Orchard, pp. $57-58$ (nos 170-174). In the Ratoldus Sacramentary, as in the Supplement to the Hadrianum, this mass set is preceded by a missa pro regibus which seemingly has its origins in the seventh century: The Sacramentary of Ratoldus, pp. 56-7 (nos 164-169); Le Sacramentaire grégorien, ed. by Deshusses, I, pp. 424-25 (nos 1266-1269).

${ }^{51}$ Ordines Coronationis Franciae, ed. by Jackson, 2 vols, I, pp. 168-200.

${ }^{52}$ Robert-Henri Bautier, 'L'avènement d'Hugues Capet et le sacre de Robert le Pieux', in Le Roi de France et son royaume autour de l'an mil, ed. by Michel Parisse and Xavier Barral I Altet (Paris: Picard, 1992), pp. 27-38.

${ }^{53}$ Guyotjeannin, 'Les évêques dans l'entourage royal sous les premiers Capétiens', in Le Roi de France et son royaume, pp. 91-98 (pp. 93-96).

${ }^{54}$ The bishops of Noyon remained closely associated with the Capetians throughout the eleventh century and were also present at the coronation of Philippe in 1059: Guyotjeannin, 'Les évêques'.

${ }^{55}$ Bautier, 'L'avènement d'Hugues Capet', p. 29.

${ }^{56}$ Although bishops of Noyon are not recorded in royal diplomata as part of the royal entourage under either Hugh Capet or Robert the Pious, they were beneficiares of royal acta issued under them: Guyotjeannin, 'Les évêques'; also his Episcopus et comes, pp. 37-40 and 'La seigneurie episcopale'. On the earlier roots of the proximity of the bishops of Noyon to the Crown, see for example Geoffrey Koziol's consideration of an early
} 
relationship is to be found not just in royal acta but in this record of the spiritual life of the church in Noyon. It is striking that a church which owed a good deal to its proximity to the Crown sought to capture the nature of royal power so accurately in the texts it used to support the liturgical round.

That the Saint-Eligius community attached significance to certain rites becomes clear when we look at where other glosses were made above the line. Such readings are relatively rare within the manuscript but include the following:

- Prayers to give penance on Ash Wednesday. These prayers, as in other copies of the Supplemented Hadrianum, are written in the masculine plural; but in Additional MS 82956 someone in a less formal hand close to that of the main scribe has gone through and amended the text above the line with an alternative femine reading. ${ }^{57}$

- Prayers for the reconciliation of penitents on Maundy Thursday. ${ }^{58}$ Prayers originally written for a (male) singular penitent, and amended above the line to allow for the possibility of plural (male) penitents.

- The ordo for the visitation of the sick was originally written for male singular, but amended to the male plural. ${ }^{59}$

- The ordo in agenda mortuorum was amended from the male singular to include both female singular and male and female plural endings. ${ }^{60}$

There is, in other words, no consistency in the nature of these changes but nevertheless it is possible to make some suggestions as to why they were made. The glosser(s) chose to focus only on rites important to the community; they felt no need to amend the rite for baptism on Holy Saturday, for example, perhaps reflecting the fact that ad hoc baptism was now more widely practiced. ${ }^{61}$ The changes made fit with a theological model of inclusivity. Thus universal rites, such as those for entry into penance, or rites for dying, were amended to ensure their universality, whilst rites of more specific relevance to the all male community of Saint-Eligius - the reconciliation of penitents, the visitation of the sick - were only amended to distinguish between singular and plural men. In other words, these glosses were made for an educative purpose; the glossers only corrected those rites where there was a need to communicate their universality. But the use of the masculine plural to address a mixed community is attested in early medieval sermons suggesting an alternative interpretation for

diploma of Charles the Simple for the bishop of Noyon which alludes to the Gelasian principle of Duo quippe: Geoffrey Koziol, The Politics of Memory and Identity in Carolingian Royal Diplomas. The West Frankish Kingdom (840-987) (Turnhout: Brepols, 2012), p. 489, citing Recueil des actes de Charles III le Simple, roi de France, 898-923, ed. by Ferdinand Lot and Philippe Lauer (Paris: Imprimerie nationale, 1949), no. 40 (901 $\mathrm{AD})$.

${ }^{57}$ BL, Addit. MS 82956, fols $184^{\mathrm{r}}-185^{\mathrm{r}}$. Compare: Le Sacramentaire grégorien, ed. by Deshusses, I, pp. 451-52; III, p. 114.

${ }^{58} \mathrm{BL}$, Addit. MS 82956, fols $185^{\mathrm{r}}-186^{\mathrm{v}}$. Compare Le Sacramentaire grégorien, ed. by Deshusses, I, pp. $452-53$.

${ }^{59} \mathrm{BL}$, Addit. MS 82956, fols 186v-189 ${ }^{\mathrm{r}}$. Compare Le Sacramentaire grégorien, ed. by Deshusses, I, pp. 453-57.

${ }^{60}$ BL, Addit. MS 82956, fols 189r-196v . Compare Le Sacramentaire grégorien, ed. by Deshusses, I, pp. 457-63.

${ }^{61}$ On ad hoc baptism see Sarah Hamilton, Church and People in the Medieval West, 900-1200 (Harlow:

Pearson, 2013), pp. 181-90. 
these amendments. ${ }^{62}$ Rather than viewing them as the product of the classroom, the decision to include women as a distinct group in the rites for Ash Wednesday and for the dying might instead reflect a performative intention on the part of the scribe. It is therefore impossible to reach any firm conclusions as to the intentions behind these amendments. What is clear is that their presence indicates a pastoral interest in the world beyond the community of SaintEligius, and that it was one which included both men and women.

A final text which points to this pastoral concern is the text for a rite which can only be administered by the bishop: the excommunication formula added on fol. $1^{\mathrm{v}}$. It is an example of an ad hoc formula. Ad hoc because, unlike formal rites for excommunication found in pontificals and canon law which script how the sentence should be imposed, and unlike formal collections of mass prayers, such as the Supplemented Hadrianum, they do not constitute a body of broadly agreed texts. ${ }^{63}$ They all follow a similar, quasi-legal structure; they begin by invoking divine authority and law, then outline the rationale for and sentence of excommunication, and its consequences, and end with curses, the opportunity to recant, and if they do not do so a curse of exclusion in this life and the next. They are usually, as here, added as an afterthought, and are not integral to the original book. This codex is now tightly bound but the ruling suggests that the folio on which the excommunication formula was written was originally a singleton. ${ }^{64}$ Unlike some additions which were made in imitative script, it is written in a less formal script; it was clearly regarded by the codex's compilers as supplementary.

The text of this particular formula is unique in the corpus of ad hoc formulae known to me. Most formulae begin by invoking the authority of the Holy Trinity. This one starts not as usually with the words 'Ex auctoritate patris et filii et spiritus' but rather by invoking the authority of the Holy Fathers that in the case of invaders of the holy church of God they should be deprived of holy rites and communion with all Christians: 'Dictis sanctorum patrum monemus et exemplis uasores sanctae dei aecclesiae'. It then continues 'ego humilis nouiomensis ecclesiae pastor cum omni grege nobis commisso excommunicando anathematizamus hos/unc \sacrilegos/um $\backslash$ et nefarios/um $\backslash$ ' ('I the humble pastor of the church of Noyon with the flock committed to me anathematize those/he $\backslash$ who have/has $\backslash$ committed sacrilege and nefarious deeds/deed ${ }^{\prime}$ '). But the next two and half lines which must once have specified the names of those offenders have been erased and cannot be detected with ultraviolet light. Perhaps this text was preserved initially as a record of the sentence. But it is worth noting that here singular readings for the number of excommunicants have been added above the line, repurposing this text so it could be used in a different situation. It seems to have been adjusted to have a more universal application. What started out as a record of a specific occasion was preserved as a guide for future use.

\footnotetext{
${ }^{62}$ E.g. Hrabanus Maurus, Homiliae de festis praecipuis, item de uirtutibus, Homilia 47, ed. by Jacques-Paul Migne, Patrologiae cursus completus: series latina, 221 vols (Paris: Migne, 1844-64), CX, col. 88C: 'Et ideo, fratres dilectissimi, sive viri, sive feminae, sive clerici seu laici, secundum Apostoli admonitionem: Mundemus nos ab omni inquinamento carnis et spiritus, perficientes sanctificationem in timore Dei'.

${ }^{63}$ On the formal rites see Sarah Hamilton, 'Interpreting Diversity'. For a consideration of the ad hoc rites see Hamilton, 'Medieval Cursing and its Uses', Haskins Society Journal (forthcoming).

${ }^{64}$ See now the description available at http://bit.ly/2BekZ9G (last accessed 21 December 2017).
} 
The excommunication formula thus reinforces the idea also suggested by the addition of prayers for the confirmation of children and the consecration of an abbot, and those for the changes to the mass for dead bishops and the daily mass for kings, that this is a book which is being maintained by a community anxious to adapt widely circulating texts to their own specific needs and traditions. ${ }^{65}$ Additional MS 82956 thus reveals Saint-Eligius as a community which valued and commemorated its past bishops. As one whose current bishop based his claims to spiritual justice on the Holy Fathers, rather than the more usual episcopal claims to Petrine authority; as one which was anxious to align its spiritual life with the new political reality of father-son kingship. ${ }^{66}$ Further, this study suggests the value to both ecclesiastical and political historians of going beyond the more occasional rites preserved in pontifical collections to investigate the contents of more mundane sacramentary collections of mass and other prayers. By examining a book composed for daily use within a community serving the bishop, in comparison with contemporary collections assembled at the same time and in the same province, it has demonstrated that the relationships of the bishops of Noyon with the temporal world were not just recorded in charters and historical writing, but also entered their daily liturgical round. In other words, if we are to gain a full appreciation of the nature of episcopacy in this period, we must heed Kantorowicz's advice and recognise the value of all types of liturgical books.

\footnotetext{
${ }^{65}$ On the use of excommunication by the bishops of Noyon in some mid-eleventh century cases see Laurent Morelle, 'Les chartes dans la gestion des conflits (France du nord, $\mathrm{XI}^{\mathrm{e}}$-début $\mathrm{XII}^{\mathrm{e}}$ siècle)', Bibliothèque de l'École des chartes 155 (1997), 267-298'; Erika J. Laquer, 'Ritual, Literacy and Documentary Evidence: Archbishop Eudes Rigaud and the Relics of St Eloi', Francia, 13 (1985), 625-37'; Geoffrey Koziol, Begging Pardon and Favor. Ritual and Political Order in Early Medieval France (Ithaca, NY: Cornell UP, 1992), p. 225.

${ }^{66}$ On episcopal claims to Petrine authority in excommunication formulae see Sarah Hamilton, 'Absoluimus uos uice beati petri apostostolorum principis: episcopal authority and the reconciliation of excommunicants in England and Francia, c. 900-c.1150', in Frankland. The Franks and the World of the Early Middle Ages. Essays in Honour of Dame Jinty Nelson, ed. by Paul Fouracre and David Ganz (Manchester: Manchester UP, 2008), pp. $209-41$.
} 